\title{
Computer Programs for ANalysis of DROPlets SPRAYed on Water Sensitive Papers ${ }^{1}$
}

\author{
Programas Computacionais para Análise de Gotas Pulverizadas em Papéis Hidrossensíveis
}

CUNHA, J.P.A.R. ${ }^{2}$, FARNESE, A.C. ${ }^{3}$, and OLIVET, J.J. ${ }^{4}$

\begin{abstract}
The use of water-sensitive papers is an important tool for assessing the quality of pesticide application on crops, but manual analysis is laborious and time-consuming. Thus, this study aimed to evaluate and compare the results obtained from four software programs for spray droplet analysis in different scanned images of water-sensitive papers. After spraying, papers with four droplet deposition patterns (varying droplet spectra and densities) were analyzed manually and by means of the following computer programs: CIR, eSprinkle, DepositScan and Conta-Gotas. The diameter of the volume and number medians and the number of droplets per target area were studied. There is a strong correlation between the values measured using the different programs and the manual analysis, but there is a great difference between the numerical values measured for the same paper. Thus, it is not advisable to compare results obtained from different programs.
\end{abstract}

Keywords: spray quality, pesticides, sprayer, droplet size, application technology.

\begin{abstract}
RESUMO - A utilização de papéis hidrossensiveis é uma importante ferramenta para avaliar a qualidade da aplicação de produtos fitossanitários nas lavouras, porém sua leitura manual é trabalhosa e morosa. Dessa forma, com o presente trabalho objetivou-se avaliar e comparar os resultados de quatro programas computacionais de análise de gotas em diferentes imagens digitalizadas de papéis hidrossensiveis. Após a pulverização, papéis com quatro padrões de deposição, variando densidade e tamanho de gotas pulverizadas, foram analisados manualmente e por meio dos programas computacionais: CIR, e-Sprinkle, DepositScan e Conta-Gotas. Foram estudados o diâmetro da mediana volumétrica e numérica e o número de gotas por centimetro quadrado. Existe forte correlação entre os valores medidos com o uso dos diferentes programas e a análise manual, porém há grande diferença entre os valores numéricos para um mesmo papel, motivo pelo qual não é recomendável comparar resultados obtidos com diferentes programas.
\end{abstract}

Palavras-chave: qualidade de pulverização, produtos fitossanitários, pulverizador, tamanho de gota, tecnologia de aplicação.

\section{INTRODUCTION}

Pesticides have been frequently used in the cultivation of major crops grown worldwide. However, its incorrect application may cause damage to human health and the environment, as well as economic losses (Gil \& Sinfort, 2005). In order for it to be an effective treatment, whether insecticide, herbicide or fungicide, the product applied must reach the target where it shall fulfill its purpose with minimal losses to the environment (Cunha et al., 2010; Bueno et al., 2011).

In this context, it is necessary to establish forms of control and evaluation of the applications of pesticides, particularly in regards to sprayers. In the spraying of herbicides, it is important to establish the

1 Recebido para publicação em 24.9.2012 e aprovado em 28.1.2013

2 Professor, CNPq Fellow, Universidade Federal de Uberlândia - UFU, PO Box 593, 38400-902 Uberlândia-MG, Brasil, <jpcunha@iciag.ufu.br>; ${ }^{3}$ Undergraduate Student, UFU; ${ }^{4}$ Professor, Doctor, Universidad de la República, Montevideo, Uruguay. 
amount of product that reaches the desired target, seeking, thereby, to reduce losses by drift. The herbicidal efficacy is connected to the deposition of the active ingredient on the weed.

The literature provides several ways to evaluate a field application (Hewitt, 2010), those using water sensitive paper as artificial targets being much employed (Zhu et al., 2011). They are originally yellow surfaces that change its color to blue in contact with water droplets. This color change occurs due to the reaction of water with the blue indicator bromophenol present in the paper.

This paper can be placed close to the target of an application, indicating the locations of the impacts produced by the droplets sprayed by a given pesticide application system. It may also indicate losses, depending on its position in relation to the target area. However, one of the negative aspects of its use is the difficulty and slowness to analyze them manually or with the aid of a magnifying glass. Other negative points cited by Cunha et al. (2012) refer to the lack of precision in high humidity environments and to the limitation in measuring droplets with a diameter of less than $50 \mu \mathrm{m}$.

In this sense, computer programs that analyze some characteristics of spraying after scanning the images of water sensitive paper are currently available. These programs were developed in order to speed up and provide greater precision to this important step in the application of agrochemicals.

However, currently there are several programs developed by different companies available in the market and that give different results for the same sample, as demonstrated by Cunha et al. (2012). These authors, comparing the results obtained by seven programs after the analysis of nine pieces of water sensitive paper, showed that there are large differences in the results between the different programs. However, in this work most employed programs in Brazil have not been evaluated.

This study aimed to evaluate and compare the results of four computer programs for the analysis of droplets in different scanned images of water sensitive paper.

\section{MATERIAL AND METHODS}

Initially, applications were made for marking the pieces of water sensitive paper $(26 \times 76 \mathrm{~mm})$ (Spraying Systems Inc., Wheaton, IL, USA). They were made using a backpack sprayer pressurized by $\mathrm{CO}_{2}$, with a boom equipped with four nozzles, nozzle spacing of $0.5 \mathrm{~m}$, and $0.5 \mathrm{~m}$ distance from the pieces of paper.

Flat-fan hydraulic spray nozzles BD11001 and flat-fan with air induction ADIA11001, made of ceramic, were employed. The pressure used was $207 \mathrm{kPa}$. We produced four patterns of deposition according to Table 1 , using both fine droplets and very coarse droplets, and displacement speed both slow and fast (corresponding to about 5 and $7 \mathrm{~km} \mathrm{~h}^{-1}$ ). Each application condition was repeated four times, resulting in 16 pieces of water sensitive paper.

After spraying, the water sensitive papers were collected and scanned by a scanner (HP Scanjet 2400) with a resolution of $600 \mathrm{dpi}$ non interpolated, with 24-bit color and BMP format, and analyzed by means of the computer programs: CIR - Conteo y Tipificación de Impactos de Pulverización (Versão 1.5, T\&C); e-Sprinkle - System for Analysis of Distribution of Natural and Artificial Droplets (Version 2005, Ablevision); DepositScan - Portable Scanning System for Spray Deposit Distribution (USDAARS); and Conta-Gotas - System for Analysis of Efficiency in Spraying (version 1.1, UEPG). The total area of the pieces of paper was analyzed by the programs.

Table 1 - Description of droplet deposition patterns on water sensitive papers and nozzles used in the test

\begin{tabular}{|c|c|c|c|}
\hline $\begin{array}{c}\text { Pattern of } \\
\text { deposition }\end{array}$ & $\begin{array}{c}\text { Spray } \\
\text { nozzle }\end{array}$ & $\begin{array}{c}\text { Droplet size } \\
\text { classification* }\end{array}$ & $\begin{array}{c}\text { Sprayer } \\
\text { displacement }\end{array}$ \\
\hline 1 & BD 11001 & Fine & Slow $\left(5 \mathrm{~km} \mathrm{~h}^{-1}\right)$ \\
\hline 2 & BD 11001 & Fine & Fast $\left(7 \mathrm{~km} \mathrm{~h}^{-1}\right)$ \\
\hline 3 & ADIA 11001 & Very Coarse & Slow $\left(5 \mathrm{~km} \mathrm{~h}^{-1}\right)$ \\
\hline 4 & ADIA 11001 & Very Coarse & Fast $\left(7 \mathrm{~km} \mathrm{~h}^{-1}\right)$ \\
\hline
\end{tabular}

* Droplet size classification, according to the manufacturer. 
For the analysis on DepositScan, images were transformed prior to 8-bit grayscale, as required by the program. Were evaluated the number median diameter $(\mathrm{NMD}, \mu \mathrm{m})$, the volume median diameter (VMD, $\mu \mathrm{m})$ and droplet density (DD, droplets $\mathrm{cm}^{-2}$ ). The DepositScan program version used does not provide the NMD.

For comparison, the papers were also analyzed manually, following the methodology adapted from Marçal \& Cunha (2008) and Cunha et al. (2012). The water sensitive papers have been expanded four times and printed on legal paper $(216 \times 330 \mathrm{~mm})$ for subsequent counting of impacts, with the aid of a magnifying glass (40x). The measurement of impacts was made directly on the scanned images using the Image Tool software (version 3.0, UTHSCSA). For this purpose, each spot (droplet print on the paper) was selected, defined and measured individually by the operator, thus reducing the problem of thresholding, used by the programs evaluated. As shown by Garcia et al. (2004), this is the most critical step for obtaining a program suited to routine analysis of droplets. In this study, the Equation (1) was used for the spread factor, proposed by Chaim et al. (1999). This factor can be defined as the ratio between the diameter of the spot, caused by the impact of the droplet on the sample surface, and the diameter of its original sphere. The programs CIR, e-Sprinkle, DepositScan and Conta-Gotas also consider a spread factor, specific to water sensitive paper, internally to its routine.

$$
\begin{aligned}
f e_{D m} & =0,74057+0,0001010399 \times D m \\
& +0,02024884 \times \ln (D m)
\end{aligned}
$$

where $f e$ is the spread factor (Adm.) and $D m$, the diameter of the spot on water sensitive paper $(\mu \mathrm{m})$.

The volume of each droplet was calculated by employing Equation (2) and the droplet diameter adjusted depending on the spread factor. Having the volume of each droplet and with the aid of a spreadsheet, we calculated the NMD and the VMD.

$$
V_{g}=\frac{\pi D g^{3}}{6}
$$

where $V_{g}$ is the volume of each droplet $\left(\mu \mathrm{m}^{3}\right)$ and $D g$, the droplet diameter $(\mu \mathrm{m})$.

As a complementary analysis, four samples of water sensitive paper, taken from the newly opened original packaging, were immediately scanned and analyzed by means of the four programs, similarly to the other pieces of paper. This analysis aimed to determine whether there would be incorrect readings of droplets in papers not subjected to spraying.

Climatic conditions during the applications were monitored through a thermohygroanemometer: average temperature of $23.1^{\circ} \mathrm{C}$, relative humidity of $63.4 \%$ and absence of wind.

The data for each program were compared with those of the manual evaluation by means of Student's t test for paired samples, at 0.05 probability $(\mathrm{p}<0.05)$. Comparisons were made considering the overall average $(n=16)$ of all pieces of paper and each deposition pattern $(n=4)$. Then, a correlation analysis between the data obtained by the programs and the manual analysis was performed by means of the Pearson correlation coefficient $(r)$. The Student $t$ test was used for analysis of this coefficient, at 0.05 probability.

\section{RESULTS AND DISCUSSION}

Table 2 shows the results of VMD, NMD and DD obtained by different analysis methods. In general, it is clear that there is a great difference between the values measured for the same piece of water sensitive paper. For the VMD, the program that provided the results closest to the manual reading in the four deposition patterns was Conta-Gotas. The CIR program always provided lower values than those of the manual reading. For the NMD, the program that came closest to the manual reading was e-Sprinkle. Again, the CIR program always provided lower values than those of the manual reading.

For the DD, considering the overall mean of the 16 pieces of paper, the program that provided the results closest to the manual reading in the four deposition patterns was Conta-Gotas. However, making the comparison by deposition pattern, DepositScan was the one closest to the manual reading. It must also be noted that the visual analysis may be subject 
Table 2 - Results obtained in the analysis of water sensitive paper through computer programs and manual analysis, considering four deposition patterns

\begin{tabular}{|c|c|c|c|}
\hline $\begin{array}{l}\text { Method of } \\
\text { analysis }\end{array}$ & $\begin{array}{l}\text { VMD } \\
(\mu \mathrm{m})\end{array}$ & $\begin{array}{l}\text { NMD } \\
(\mu \mathrm{m})\end{array}$ & $\begin{array}{c}\text { DD } \\
\left(\text { droplets } \mathrm{cm}^{-2}\right)\end{array}$ \\
\hline \multicolumn{4}{|c|}{ Overall means $(n=16)$} \\
\hline CIR & $237.05^{*}$ & $106.50 *$ & $140.00 *$ \\
\hline e-Sprinkle & $514.91 *$ & $223.26^{\mathrm{ns}}$ & $13.46^{*}$ \\
\hline DepositScan & $548.97 *$ & - & $30.99 *$ \\
\hline Conta-Gotas & $387.69^{\mathrm{ns}}$ & $111.56^{*}$ & $58.25^{\mathrm{ns}}$ \\
\hline Manual & 409.42 & 193.51 & 47.55 \\
\hline \multicolumn{4}{|c|}{$\begin{array}{l}\text { Deposition pattern }=\text { fine droplets and slow displacement } \\
\qquad(\mathrm{n}=4)\end{array}$} \\
\hline CIR & $141.49 *$ & $51.91 *$ & $359.25^{*}$ \\
\hline e-Sprinkle & $282.70^{\mathrm{ns}}$ & $215.80 *$ & $20.63 *$ \\
\hline DepositScan & $339.00 *$ & - & $80.54 *$ \\
\hline Conta-Gotas & $215.25^{\mathrm{ns}}$ & $105.75^{\mathrm{ns}}$ & $121.75^{\mathrm{ns}}$ \\
\hline Manual & 264.93 & 86.35 & 42.42 \\
\hline \multicolumn{4}{|c|}{$\begin{array}{c}\text { Deposition pattern = very coarse droplets and slow } \\
\text { displacement }(\mathrm{n}=4)\end{array}$} \\
\hline CIR & $316.78 *$ & $113.31 *$ & $84.00 *$ \\
\hline e-Sprinkle & $691.60 *$ & $200.85^{\mathrm{ns}}$ & $13.78^{\mathrm{ns}}$ \\
\hline DepositScan & $745.33^{*}$ & - & $16.99^{\mathrm{ns}}$ \\
\hline Conta-Gotas & $482.00^{\mathrm{ns}}$ & $125.50 *$ & $40.25^{*}$ \\
\hline Manual & 579.68 & 216.28 & 19.37 \\
\hline \multicolumn{4}{|c|}{$\begin{array}{l}\text { Deposition pattern }=\text { fine droplets and fast displacement } \\
\qquad(\mathrm{n}=4)\end{array}$} \\
\hline CIR & $146.42 *$ & $141.18 *$ & $56.75^{*}$ \\
\hline e-Sprinkle & $242.30^{\mathrm{ns}}$ & $242.30^{\mathrm{ns}}$ & $11.65^{\mathrm{ns}}$ \\
\hline DepositScan & $294.09 *$ & - & $12.19^{\mathrm{ns}}$ \\
\hline Conta-Gotas & $379.25 *$ & $109.25 *$ & $29.75^{*}$ \\
\hline Manual & 244.44 & 229.65 & 14.80 \\
\hline \multicolumn{4}{|c|}{$\begin{array}{c}\text { Deposition pattern = very coarse droplets and fast } \\
\text { displacement }(\mathrm{n}=4)\end{array}$} \\
\hline CIR & $343.52^{*}$ & $119.58^{*}$ & $60.00 *$ \\
\hline e-Sprinkle & $843.05^{*}$ & $234.10^{\mathrm{ns}}$ & $7.78^{*}$ \\
\hline DepositScan & $817.48 *$ & - & $14.23^{\mathrm{ns}}$ \\
\hline Conta-Gotas & $474.25^{\mathrm{ns}}$ & $105.75^{*}$ & $41.25^{*}$ \\
\hline Manual & 548.62 & 241.78 & 13.60 \\
\hline
\end{tabular}

VMD - volume median diameter; NMD - number median diameter; DD - droplet density. Means followed by a $*$ indicate significant difference compared to manual analysis by t test at $5 \%$ probability $(\mathrm{p}<0.05) .{ }^{\text {ns }}$ Not significant $(\mathrm{p}>0.05)$

to errors in counting and measuring, mainly due to the difficulty of the process. Another possible source of error is the use of different spread factors in computer routines. The programs CIR, e-Sprinkle and Conta-Gotas, for example, do not cite the factors employed. The program DepositScan employs the factor proposed by Salyani \& Fox (1994).

CIR always provided the highest droplet density. A similar observation was also made by Leiva $\&$ Araújo (2009), which claim that this fact is probably due to the greater sensitivity of this program to perform the separation of overlapping drops. In general, the programs present computational routines that allow the separation of superimposed droplets due to their spherical shape. However, given the travel speed of the sprayer, a droplet may present elongated shape, which could lead to errors in the overall result by the program.

Garcia et al. (2004) showed that the analysis performed by computer programs to quantify and qualify the spraying process also showed very different results when compared to traditional methods of analysis. The authors attributed errors mainly to filters for separating the background color of the paper (yellow) from the droplets' color (blue). The analysis of scanned images of yellow paper with blue spots caused by droplets seems simple, but the authors have identified about 90 shades of colors between yellow and blue. For an examination of droplets whose size is to the order of microns, the difficulty increases.

Regarding the correlation analysis (Table 3), it is observed that it was statistically significant among all measurement systems for the $\mathrm{DD}$ and the VMD, with no significant value for the NMD, considering the comparisons: Manual x e-Sprinkle, Manual x Conta-Gotas, CIR x e-Sprinkle and CIR x ContaGotas. According to the classification by Davis (1971), correlation values above 0.70 indicate a strong positive correlation, which can be seen that for the values associated to DG and DMV.

Although there is not always numerical agreement between the measured values, this strong correlation allows users of sensitive papers to be confident that their results are comparable for the same test, provided they have been assessed by the same program, regardless of the measurement system used. For comparison of treatments, all programs would deliver similar conclusions based on size and density of droplets. Similar results, comparing the programs USDA, DropletScan 
Table 3 - Correlation coefficient between measurements obtained by manual analysis and by use of computer programs CIR, eSprinkle, DepositScan and Conta-Gotas, for VMD, NMD and DD

\begin{tabular}{|l|c|c|c|}
\hline \multirow{2}{*}{\multicolumn{1}{c|}{ Correlation }} & \multicolumn{2}{c|}{ Correlation coefficient } \\
\cline { 2 - 4 } & VMD & NMD & DD \\
\hline Manual x CIR & $0.8728^{*}$ & $0.9120^{*}$ & $0.9854^{*}$ \\
\hline Manual x e-Sprinkle & $0.9396^{*}$ & $0.1236^{\text {ns }}$ & $0.7389^{*}$ \\
\hline Manual x DepositScan & $0.9380^{*}$ & - & $0.9504^{*}$ \\
\hline Manual x Conta-Gotas & $0.6709^{*}$ & $0.1866^{\mathrm{ns}}$ & $0.9704^{*}$ \\
\hline CIR x e-Sprinkle & $0.8858^{*}$ & $0.1535^{\mathrm{ns}}$ & $0.7799^{*}$ \\
\hline CIR x DepositScan & $0.9609^{*}$ & - & $0.9806^{*}$ \\
\hline CIR x Conta-Gotas & $0.7744^{*}$ & $0.2437^{\mathrm{ns}}$ & $0.9857^{*}$ \\
\hline e-Sprinkle x DepositScan & $0.9613^{*}$ & - & $0.8582^{*}$ \\
\hline e-Sprinkle x Conta-Gotas & $0.6337^{*}$ & $-0.5656^{*}$ & $0.7786^{*}$ \\
\hline DepositScan x Conta-Gotas & $0.7096^{*}$ & - & $0.9702^{*}$ \\
\hline
\end{tabular}

VMD - volume median diameter; NMD - number median diameter; DD - droplet density. ${ }^{*}$ Significant at $5 \%$ probability $(\mathrm{p}<0.05)$. ${ }^{\text {ns }}$ Not significant $(\mathrm{p}>0.05)$. The DepositScan program does not provide NMD.

and Swath Kit, were also found by Hoffmann \& Hewitt (2005), who found good correlation between the data provided by the three programs, even with the use of different spread factors.

Regarding the analysis of the pieces of paper newly-removed from the original packaging, were obtained $0 ; 0 ; 0.37$ and 155 droplets $\mathrm{cm}^{-2}$, respectively for the programs CIR, e-Sprinkle, DepositScan and Conta-Gotas. This demonstrates that there is some inconsistency in the Conta-Gotas program, in the version used for reading papers with no signs of droplet impact.

There is a strong correlation between the values measured using different computer programs and the manual method for volume median diameter and droplet density, allowing greater confidence in treatment comparison of a test evaluated by the same program, regardless of which it is. However, there is a great difference between the numerical values given for the same water sensitive paper, thus it is not advisable to compare results obtained with different programs.

\section{ACKNOWLEDGMENTS}

The authors acknowledge the financial support of the Brazilian funding agencies, FAPEMIG - Fundação de Amparo à Pesquisa do
Estado de Minas Gerais and CNPq - Conselho Nacional de Desenvolvimento Científico e Tecnológico.

\section{LITERATURE CITED}

BUENO, M. R. et al. Estudo do espectro de gotas produzidas nas pulverizações aérea e terrestre na cultura da batata. R. Ci. Agr., v. 54, n. 3, p. 225-234, 2011.

CHAIM, A.; MAIA, A. H. N.; PESSOA, M. C. P. Y

Estimativa de deposição de agrotóxicos por análise de gotas. Pesq. Agropec. Bras., v. 34, n. 6, p. 963-969, 1999.

CUNHA, J. P. A. R. et al. Aplicação aérea e terrestre de fungicida para o controle de doenças do milho. R. Ci. Agron., v. 41, n. 3, p. 366-372, 2010.

CUNHA, M.; CARVALHO, C.; MARÇAL, A. R. S. Assessing the ability of image processing software to analyse spray quality on water-sensitive papers used as artificial targets. Biosyst. Eng., v. 111, n. 1, p. 11-23, 2012.

DAVIS, J. A. Elementary survey analysis. Englewood: Prentice-Hall, 1971. 206 p.

GARCIA, L. C.; RAMOS, H. H.; JUSTINO, A. Avaliação de softwares para análise de parâmetros da pulverização realizada sobre papéis hidrossensíveis. R. Bras. Agrocomp., v. 2, n. 1, p. 19-28, 2004.

GIL, Y; SINFORT, C. Emission of pesticides to the air during sprayer application: A bibliographic review. Atmosp.

Environ., v. 39, n. 28, p. 5183-5193, 2005. 
HEWITT, A. J. Tracer and collector systems for field deposition research. Aspects Appl. Biol., v. 99, n. 1, p. $283-289,2010$.

HOFFMANN, W. C.; HEWITT, A. J. Comparison of three imaging systems for water-sensitive papers. Appl. Eng.

Agric., v. 21, n. 6, p. 961-964, 2005.

LEIVA, P. D.; ARAUJO, E. C. Comparación de programas de computación para recuento y tipificación de impactos de aspersión sobre tarjetas sensibles. Pergamino: INTA, 2009. $7 \mathrm{p}$.
MARÇAL, A. R. S.; CUNHA, M. Image processing of artificial targets for automatic evaluation of spray quality. Trans. ASABE, v. 51, n. 3, p. 811-821, 2008.

SALYANI, M.; FOX, R. D. Performance of image analysis for assessment of simulated spray droplet distribution.

Trans. ASAE, v. 37, n. 4, p. 1083-1089, 1994.

ZHU, H.; SALYANI, M.; FOX, R. D. A portable scanning system for evaluation of spray deposit distribution. Comp. Electr. Agric., v. 76, n. 1, p. 38-43, 2011. 